\title{
The Development of Science Concept in Turkey and Effects of Constructivism on 2004 Primary Science Curriculum
}

\author{
Faruk Öztürk \\ Correspondence: Faruk Öztürk, Faculty of Education, Abant Izzet Baysal University, Bolu, 14280, Turkey
}

Received: January 6, 2016 Accepted: January 15, 2016 Online Published: January 28, 2016

doi:10.11114/jets.v4i4.1283 URL: http://dx.doi.org/10.11114/jets.v4i4.1283

\begin{abstract}
The aim of this study is to examine the development of science concept in Turkey. It is seen that the historical process of science concept in Turkey has developed within two stages. The first setting is the later stages of the Ottoman State and the Republican Era, at which time positivism was prevalent as noted in the objectives of the national science curriculum. The second stage includes the period starting from 2004 to the present when the effects of postmodern epistemology started to partially be seen with the initiation of the new elementary curriculum based on a "constructivist approach". Positivism entered into the Ottomans during the 19th century and it affected especially the school programs. During this process, at first the positivist/modernist paradigms and later on the postmodernist paradigms affected the curricula scientifically and epistemologically. This study was based on document analysis approach. The documents used in this study were selected to represent the science curriculum of 1913, 1924, 1926, 1930 and 2004 programs. The document analysis revealed that the remained effects of positivism is observed until 2004 program. Even though, there is no deviation from the basic paradigm regarding scientific understanding until the 2004 program, the 2004 program reflects a fundamental break from the traditional approach to constructivism.
\end{abstract}

Keywords: science, elementary science curriculum, positivism, constructivism

\section{Introduction}

This study is based on the argument that the introduction of science in a western sense into the field of education in Turkey has occurred in an intellectual, ideological and political framework between Turkey and the West. In other words, positivism was a main factor in the process known as the Modernization or Westernization of Turkey, during which time scientific advancements in the West were followed closely (Gök, 1999; Özlem, 2002). At the same time, I argue that postmodern approach, as a reaction to the positivist science approach, was also included as an intellectual, ideological and political framework between Turkey and the West. Both the positivist/modernist paradigm and, more recently, the postmodernist/postpositivist pradigm have become scientifically and epistemologically powerful in the field of education, specifically as influences to the national curriculum and its acutalization ( Ünder, 2010). In the history of education in Turkey, science as it pertains to curriculum, is the area in which this shift was most significant. Thus, the present study aims to identify the epistemological approaches that impacted the objectives and outcomes of the Elementary Science and Technology Curriculum in the past - during the later stages of Ottomans and the Republican era - as well as the new curricula of 2004. In addition, the study also aims to evaluate the transformation experienced in national curriculum objectives and outcomes as paradigms shifted or overlapped.

It may be argued that a shift occurred from a positivist approach, which was claimed to lie at the heart of the Turkish Education System until the 2000's, to a new thinking style and a paradigm change. The shift has been from the deterministic and linear thinking style of positivism to a postmodernist/constructive thinking style.

Constructivism has manifested itself in other fields as well. Constructivism can be divided into three categories: pedagogical, psychological and epistemological. Pedagogical constructivism mostly relates to learning, is based on the results of psychological constructivism, and aims to give students the science knowledge that exists in practice - the knowledge of "normal science" in Kuhn's terms. The recommendations of pedagogical constructivism are the progressive recommendations of epistemological constructivism that are followed in Turkey and around the world (Ünder, 2010). Psychological constructivism is a learning theory. It tries to explain how children form conceptual schemes and beliefs, and how they learn (construct their knowledge). It generally refers to the learning theories of Piaget and Vygotsky. Constructivism as an epistemological/radical view proposes certain hypotheses which pose 
problems in the relationship between the knower and the known in issues such as the role of subject-object relationship, knowledge, truth, reality, scientific theories, scientific methods and observation, and which position the knower (the subject) at the center. According to the radical constructivist approach, the subject cannot surpass the boundaries of individual experience, and there is no world for the subject other than his own subjective experience (Glasersfeld, 2004). In addition, knowledge cannot be received passively through the senses or communication. It is constructed actively by the knowing subject. Constructivism as an epistemological/radical approach breaks the link between beliefs or concepts actively constructed by the subject, in Glasersfeld (2004)'s words, and reality. It insistently emphasizes the subjectivity dimension of knowledge and associates it with beliefs. Therefore, the epistemological/radical constructivist approach is in the postmodernist and postpositivist realm.

This study thus contains a critical analysis of the constructivist framework which is claimed to lie at the heart of the 2004 elementary science program by the Ministry of Education. The theoretical framework of the study is radical constructivist theory. The goal for my analysis is to identify the effects on the 2004 national elementary science program of radical constructivist approach to curriculum development. My guiding question as framed by radical constructivism is: How consistent is the perception of knowledge in a national elementary science program that is framed by radical constructivism? The epistemological coherence between outcomes and the approach is studied in relation to this theory. The "critical approach" mentioned in the study refers to an analysis/evaluation of the coherence of the program within radical constructivist arguments.

This paper has three sections. The first section will focus on the introduction of positivism in Turkey and its relation to the concept of science, attributed meanings, and transformations. The second section will reveal the reflections of positivism in the objectives of the Elementary Science Curriculum from the Ottoman time to our day, followed by a discussion of the effects and reflections of the approaches prevalent in the 2004 Elementary Science and Technology Curriculum (positivism and postmodernism/constructivism). As mentioned in an official announcement by the Ministry of National Education (MNE) and in the objectives of the Elementary Curriculum dated 2004, the main feature of the curriculum was that the "radical constructivist approach" (MNE, 2006, p. 8) was taken as a learning approach. As this curriculum was based on the constructivist approach which is considered to be the postmodernist epistemology translated into education (Cromer, 1997; Fleury, 1998), the 2004 Elementary Curriculum was described as 'postmodern'.

This study was conducted by analyzing curriculum documents starting from the Reform period under the Ottomans, including Primary and Secondary School Curriculum, (1913), Curricula of Elementary Schools, (1924, 1926 and 1930) Elementary Science and Technology Course (Grades 4 and 5) Curriculum (2005), Elementary Science and Technology Course (Grades 6,7,8) Curriculum (2006) and other official documents.

This study was based on document analysis approach. The documents used in this study were selected to represent specific historical sections and descriptive analysis of data obtained from this approach, based on historical documentation were examined. During the descriptive analysis process, the programs of the course topics, learning outcomes (gains) and epistemelogic language and propositions used in expressions such as objectives were discussed through an analytical approach. Almost all of these documents that are subject to the review are school programs. The criteria in the selection of the document are the education programs used in the historical periods that form the framework of the study. This is because primary education, science programs in 1913, 1924, 1926 and 1930 the understanding of scientific knowledge was framed by positivism. Positivism remained the framework until 2004. There is no deviation from the basic paradigm regarding scientific understanding. However, the 2004 program reflects a fundamental break from the traditional approach in that positivism was replaced by constructivism as the national curriculum framework. The comparison of the selected science programs with the dates mentioned above (the last quarter-century of the Ottoman Empire and the Republic period, dated 2004) forms one of two fundemental sections aims of this study.

\section{The Development of Science Concept in Turkey}

The early science courses in the history of Turkish education partially referred to science and partially to the technology and technical knowledge of the West. In the later stages of the Ottoman state, science in the field of education and science instruction involved positive sciences. The first person to refer to positive sciences, Katip Çelebi (the pioneer of the Ottoman Renaissance) was also the first person to mention the science and scientific thought (as a practical field of science) when he proposed the abandonment of the scholastic style produced by the Madrasa (Islamic theological school) in favor of the Western approach of positivist attitude and science (Adivar, 1982). In classical schools (Madrasa), courses such as science and science studies refer to courses based on positivist knowing and knowledge production styles. These are what we know today as the natural sciences or physics, chemistry, biology and physiology. For instance, when discussing curricula in the 19th century (during the Reform Period), Ali Suavi stressed the fact that 
"science needs to be known by all students in our day" (Ülken, 1992, p. 87). According, the concept of education is taken as a practical field of science (Koçer, 1987).

As is well known, positivism is an effective science philosophy emerged in the West in the 19th century. Movements underlying the positivist epistemology developed in the West are based on the process of advancing scholastic knowledge forms, counter factual and rational understanding of nature and forms of knowledge creation. A positivist approach relating to the first periods in the study means tending to experimental and factual science. Before the 19th century, Ottoman statesmen and thinkers became aware of this paradigm shift emerging in the West (Kafadar, 2000; Özlem, 2002). Orientation to the West and interaction with its scientific knowledge moved to the top spots during the Tanzimat era with a positivism invitation letter sent by A. Comte to Prime Minister M. R. Pasha, dated 1853 (Berkes, 1987). As a result of this interaction positivist ideas entered into the Ottomans during the 19th century and it affected especially the school programs and programs of applied science and math courses deeply (Gök, 1999).

In the scientific thinking of the Ottomans, positivist orientations first manifested themselves officially in the curricula of military schools. ${ }^{1}$ These curricula particularly became the entry point of this impact. Ottoman statesmen and intellectuals started to emphasize that science could play a pioneering role in development and advancement (Kafadar, 2000). This orientation of the Reform period clearly reveals the shift in the perception of Western science. Such a change in perception could only be extended to the entire country through educational institutions. It was believed that science and technology could be achieved by organizing education in accordance with this change in perception (Berkes, 1978). In line with this belief, both new schools and universities as an alternative to the existing higher education (madrasa) were deemed necessary. In 1846, the report presented to Sultan Abdulmajid by the Educational Council emphasized that "a university needs to be established independently from the madrasa in order to teach all science and technology needed" (Unat, 1964, p. 90). On the other hand, the first positivist thinking styles started to take root with the work of certain non-governmental groups. To illustrate, groups such as the Beşiktaş Science Society (1815) and the Ottoman Science Society (1861) used science and technology heavily in their programs. These clubs aimed at developing 'science' and 'science education'. Their founders were scientists educated in the west, particularly in positivist sciences, and thus became introduced to positivist thought. ${ }^{2}$ The advancement of the scientific approach or the strengthened belief in the importance of science and technology seen in scientific and educational institutions from the early 18th century onwards stemmed both from the need for a positivist epistemology and, perhaps more, from a yearning for more development and escape from underdevelopment (Bahadır, 2001). Some Ottoman statesmen and intellectuals saw appropriate and modern experimental and conceptual knowledge as a requirement of their age, and believed that this was the only path to social advancement and development. ${ }^{3}$

According to the prevalent belief in the late Ottoman time, becoming westernized was a prerequisite to development. As positivism was synonymous with science in the West, becoming westernized meant becoming positivistic. Positivism in this sense functioned as a method rather than an epistemological trend in the modernization process from the Reform

${ }^{1}$ The text book Mathematical Sciences (Mecmua-i Ulum-i Riyaziye) written by Ishak Efendi, the principal of the first Military School, used the terms science and mathematics for the first time. He also translated Introduction l'Etude de la Médecine Expérimentale, the pioneering book for positivism in biology, written for medical education in 1865 by Claude Bernard (Mardin, 1992).

2 The aim of the Ottoman Science Society was to 'introduce the Anglo-Saxon understanding of science to the country' (Berkes, 1978). The publication of the society, Journal of Science (Mecmuay-ı Fünun), was the first to disseminate science articles. The aim of the articles and conference talks given by intellectuals such as the Chemist Derviş Pasha was to give information about new sciences, to encourage the development of industry and the enlightenment of minds (Berkes, 1978) and to promote the adoption of western science and techniques. These early efforts marked the introductory phase of western materialism, positivism and humanism into the country. This introduction naturally happened through science education.

${ }^{3}$ Having played an important role in the introduction of positivism to the country and being known as the first positivist, the author Beşir Fuat was a proponent of Western thinkers Voltaire, Diderot, La Mattrie, Comte and so on. On the other hand, Baha Tevfik's work coincides with the winds of Ludwig Büchner in Europe. In his books, Tevfik largely reflected the effects of Buchner and thus materialism. Beşir Fuad and Baha Tevfik made use of Ernest Haeckel and Büchner's theories of materialism and biological evolution and translated their works into Turkish. In later years, the materialist understanding of 'science' and the positivist approach advocated in Büchner's book Kraft und Stoff were to become determning forces in both education and politics. In addition to these, the works of European thinkers such as Gustave Le Bon, Jean Marie Guyau, Meslier, Herbert Spencer, Fouillée, and Durkheim were also among the very first translations (Mardin, 1993). 
period (1839) to the Republic (1923). It also entails an applicable, practical conceptual structure. This process of legitimization based main concepts on scientific knowledge, not on abstract, religious or narrative sources. During this process, science and scientific thought almost became divine, and the old divine was replaced with positivist science, as in the Western age of Enlightenment. One of the most prominent features of late Ottoman positivism was the inspiration it found in German materialism, which was based on natural sciences and medical experiments. This continued and encouraged the founders of the Republic to go beyond being academic by adopting the principle of the unconditional superiority of science (Hanioğlu, 2008).

During this period when Ottoman intellectuals were introduced to Western schools of thought, they had no choice but to imitate them as they lacked the skills of developing philosophical/intellectual alternatives to these trends. The modernization of all non-Western societies occurred without the Western period of enlightenment (Özlem, 2002). Therefore, these first influences were of a social and political nature rather than being an epistemological movement. With this inspiration, the dream of reengineering the society flourished. The young intellectuals being educated in the new public schools established to modernize bureaucracy saw Comte's positivist science approach as the most valid method in reorganizing the society (Mardin, 1993). What lies under this dominant thought was the belief that development could happen with the methods and findings of positivist science. Owing to this, even though Ottoman intellectuals were mainly influenced by Western materialist and positivist styles of thinking and 'knowing' after 1870, they adopted French positivism in scientific and political thought. It should be noted that the positivism that Ottoman intellectuals advocated in this era basically meant valuing physical phenomena (Mardin, 1993). Even though there were shifts at times, the positivist thought that influenced education and science, and particularly politics, remained Comte's classical positivism. During the Republican era, classical positivism was superficially influential in all areas and particularly in curricula until the 1950s, after which Anglo-Saxon positivism became more prevalent (Özlem, 2002). The superficiality comes from using Western science and technology for advancement and social order, rather than referring to an epistemologically based finding.

\section{The Transformation of Science Teaching from Ottoman Era to the Republican Era}

The science topics taught in today's Science and Technology Course in elementary education were taught under different names and including partly different content during Ottoman times. Some topics covered by science studies were included in elementary education in the course objectives? (Science and Technology Course Objectives). During the Ottoman time, a science course was first included in the Military College curriculum in 1847 with the name Philosophy of Nature / Physics (İlmi Hikmet-i Tabiye)(Koçer, 1987). This course only featured in the curricula of civilian schools (Secondary Education) during the Reform period.

The first comprehensive curriculum during the Ottoman times started with the General Educational Regulation (Maarifi Umumiye Nizamnamesi) in 1869. This document included the courses to be offered in secondary and high schools. In the category of science, they offered Natural Sciences (Ilmi Mevalid) and Philosophy of Nature. The latter was a science course that included topics such as mechanics, attraction, magnetism, sound, light, electricity (Ministry of General Education $[\mathrm{MGE}]{ }^{4}$ 1913). Natural Sciences included the topics of animals, plants and minerals. The science courses taught in secondary and high schools generally covered "physiological information such as the human body and the functions of organs, and basic information about plants, the earth and minerals and the protection of health" (MGE, 1913, p. 56). As the curricula written during this era did not include explicit program goals and objectives, an examination of the the topics covered in text books revealed the use of the positivist approach. These topics had previously not been covered in Madrasa curricula.

During the 2nd Constitutional period, there was an awareness of the necessity of science and technology, and a determination to keep up with developments and sustain the achievements of the Reform period. ${ }^{5}$ Educational methods that could be taken as indicators of the positivist approach were prominent in the content and processes of science courses. Perhaps the most prominent of these was the emphasis that Sat1 Bey made on experiment and observation based approaches following his appointment as the principal of Teachers College (Darülmuallimin) in 1909. Learning through research and discovery and the visual method of observation/instruction were the basic elements of teacher training curricula during this period. Positivist methods of knowledge production and learning such as experimenting,

\footnotetext{
${ }^{4}$ MGE: Ministry of General Education (Ottoman era)

${ }^{5}$ The political movements of the 2nd Autocracy period were significantly affected by the science books taught especially in military and medical schools, which were translations of the materialist and positivist philosophies from the West. The members of the first Ottoman political party, Ittihat ve Terakki, were generally graduates of these schools. Almost all of them admired courses and books such as Biology, Physiology, Anatomy, Pathology, and Botanics as they did not include religious explanations (Mardin, 1993).
} 
research, and observation became the pillars of education during this era. These approaches were evident in both the text books and journals of the era. ${ }^{6}$

During the late Ottoman period, the general belief was that advancement and development would come from science and technology, which could only be achieved through education. Thus, increased importance was attached to science and technology based schools and courses. Even though there were efforts to reverse this trend during the Autocracy period, the general tendency could not be stopped and it developed parallel to historical advancement and general positivist attitude. During the Republican era, there were efforts to make science and technology the basis of all other fields. The scientific approach was seen as the source of social, economic and scientific advancement, and all intellectual attitudes pertaining to the past (the scholastic period) had to be abandoned (Berkes, 1978). In a general sense, education and ways of knowledge production were rid of their religious quality and given a secular nature.

\section{The Republican Era Primary School Curriculum and Science Teaching}

The main aim of the educational approaches during the Republican era was to extend positivist science to the country. Atatürk stated this aim in a parliament speech in 1923 by saying "science is what the children of this nation need" (Ataünal \& Özalp, 1977, p. 35). This revolution transformed the culture and education at the heart of the society and the state, and a positivist education approach was adopted (Gök, 1999). The courses where this point of view was most effectively and functionally disseminated were those focusing on positivist science. Thus, the priority of topics and courses relating to science and technology, such as science studies, was reiterated. The teaching and learning of science was included in elementary schools for the first time in 1924. It was also the first time in the educational history of the country that objectives had been specified for a particular course. The elementary curriculum of 1926 was particularly functional and based on real life and reflected student effectiveness thanks to John Dewey's report on the Turkish education System and the general tendency in the country (Binbaşığlu, 1999).

The classical positivist approach was evident in the objectives of the Natural Examination, Agriculture, Health Protection (Hifzissihha) in the Elementary Curriculum course in 1924 and 1925:

"To make children examine every living thing in their natural environment with all their vital stages ..." "To teach the effects of humans on the nature and nature on humans and organic beings on one another ... To teach human organs and their functions ..." (MV, 1340[1924], p. 38-44).

In addition, certain principles about how to teach this course were also included. The positive science approach and knowledge production methods were used in these principles. These principles include the following: "The topics of animals and plants through observation and experiments on living samples. The students should record the outcomes of their observation and experiments." (MV, 1341[1925], p. 40)

Methods such as experimentation, observation, and research in an authentic environment were recommended for teaching science, and it was stated that lecturing and theoretical presentations should be avoided. The recommended methods were research/investigation, observation, observation in an authentic setting, teaching scientific principles, presentation of physiological structures, examining samples, comparison, working on cadavers and autopsy, summarizing research results and evaluation and discussion (MV, 1340 [1924]). In addition to these methods, aims such as "giving students practical information about everyday objects and introducing the laws obtained through scientific processes" (MV, 1340[1924], p. 38) are methods and processes that belong to positive knowing and knowledge production processes.

In the Republican era, the positivist approach fully established itself in education. In positivism, being scientific is not only a tool for economic and social advancement, but it is a primary dynamic of social history and a method necessary in all walks of life (Bahadır, 2001). In a speech delivered in Bursa, Atatürk defined the education he envisioned for the country as “...based on positive science and free of the past’s superstitions" (Başgöz, 1995, p. 277). It was stated that types of knowledge production other than the dominant positivist science had lost their validity. The reformist positivist approach, which had been embraced since the Reform era, was redefined in the Republican period as scientific rationality and as the 'most substantial guide' (Yavuz, 2009).

\subsection{Science and Technology Curriculum and Constructivism}

In the era mentioned above, despite the positivist approach following from a materialist ontological base and the dominant discourse of the day, a different approach for today's paradigms existed. This different approach is defined as

${ }^{6}$ The articles titled Teaching of Natural Sciences (p. 98-105) and The Science Studies Course (p. 225-231), published in the Journal of Teaching (Tedrisat Mecmuast) in 1912 in issue 20 and in 1914 in issue 24 respectively, aimed to inform teachers about approaches such as the use of experimentation, observation and materials in science education courses. 
the constructivist learning approach based on the postmodern/postpositivist epistemology. The constructivist approach, and particularly radical constructivism that appeared epistemologically, mainly emphasizes what knowing is and how it is achieved (Phillips, 1995; Fosnot, 2005), rather than emphasizing the teaching and learning processes. Knowledge is taken as developmental, objective and applicable/consistent explanations, not transmitted and discovered truths. During the transition to the postmodern age, Turkish curricula also became affected by the transformation of science and knowledge which was observed throughout the world as a result of globalization.

In the 2000's, both politicians and MNE officials have declared that the constructivist approach which underlies the new curricula questions positivist science (Birinci, 2006). They have also stated that the link between events and phenomena are probabilistic, and war has been waged on scientific determinism, because the principles of positivism are universalist and prohibitive (Birinci, 2006). MNE officials go beyond a criticism of positivist science and theory of knowledge and mention the legitimizing effects of positivism on the social and political structure. With this aim in mind, they seem to embrace the constructivist approach with a political rather than epistemological motive. The indicators of this will be presented later when curricular objectives are being evaluated.

Having become the most prominent approach after the 1980's, constructivism became an officially adopted 'approach' by the MNE in their curriculum development endeavors after 2004. Elementary and secondary curricula were renewed according to the constructivist approach, and became the official philosophy of education in Turkey, as in many other countries (Ünder, 2010). In the objectives and curricular vision sections of the 2004 Science and Technology Curriculum, constructivism is evident as "a learning approach" as it provides a "useful and functional framework although other learning theories have not been totally eliminated" (MNE, 2006, p. 12). In addition, it was also stated in this document that "various active learning strategies have been given a prominent place in the instructional process as an extension of this approach" (MNE, 2006, p. 13).

Certain statements from the objectives, curricular vision and learning outcomes sections of the Science and Technology Curriculum show that it reflects the constructivist epistemology. For instance, in the introduction, the characteristics of science are listed as follows (MNE, 2006):

"Science is contributed to by scientists from all world cultures ..."(p. 4),

"Science is enriched by women and men from different cultures ..." (p. 4),

"Science is an individual and social activity" (p. 8),

"Science theories are continuously reviewed", ... "revised and improved" (p. 12),

"Academic discussions involve mutual dialog and convincing ..." (p.12),

"Science is affected by social, cultural, economic and religious factors and individual and/or social prejudice" (p. 23). Such statements reflect the constructivist approach which does not see science as a static and unchanging set of facts and implies that it involves an efficient and organized process (Glasersfeld, 2005a ; Julyan \& Duckworth, 2005).

At the same time, the curriculum also adopts an understanding of science that is not dogmatic towards the accuracy of scientific knowledge, but admits that it is fallible. To illustrate, some of the outcomes of the Science and Technology course include statements such as "the current facts about space are limited and may change in the future in light of new research ... scientific knowledge does not include unchanging truths, but current best explanations" (MNE, 2005, p. 282). Such statements are in line with the subjective fallibilism of postmodern science which advocates that knowledge accumulated in the form of existing scientific propositions can always be challenged (Lyotard, 1999). Statements about learning, such as "knowledge and skills cannot be transmitted from teacher to students", "personal knowledge, views, beliefs affect learning", and "knowledge and understanding is constructed personally by individuals and socially" (MNE, 2006, p. 13) also reflect the constructivist learning approach. However, it is also true that the curriculum contains certain dimensions that are in conflict with the constructivist approach adopted as its main philosophy7. Even though the curriculum claims to have based itself on the constructivist philosophy, it remains close to the positivist approach in many regards. These may be listed as follows:

\subsection{Learning Approach and Instructional Strategies}

In the curriculum designed by the MNE, no clear meaning has been attached to constructivism. At times it is referred to as the "Constructivist learning approach", and at others as the "main philosophy" (MNE, 2006, pp. 66-67). However, it has been argued that constructivism is merely a learning approach and curricular objectives describe it as an [effective]

\footnotetext{
${ }^{7}$ Even though the concept of 'main philosophy' may be ambiguous, it is synonymous with radical constructivism which focuses on the mental activity of learning individuals and refers to the epistemological basis of constructivism as it is different from the phrase learning approach.
} 
theory [epistemology] about how knowledge is obtained. Even though constructivism is not an instructional theory (Fosnot, 2005), this curriculum holds it responsible for developing effective instructional approaches (MNE, 2006). It has been stressed that constructivism should be used as a different approach and almost as an instructional theory. In fact, what the science curriculum does is not offer a constructivist epistemology, but makes use of the alternative offered by the approach in the instructional process. The curriculum both takes the constructivist approach as its main philosophy and announces science as a course most unaligned with the constructivist learning approach. In this way, it implies that the approach will only be used in instructional activities. This confusion may be a result of postmodernism intertwining epistemological and pedagogical criticism, and its failure to clearly distinguish learning the nature of science from learning science (Schulz, 2007). In brief, the curriculum does not reflect the awareness that scientific epistemology is different to the epistemology of the learner.

Considering instructional strategies, the statement that "the curriculum prioritizes the constructivist learning approach" (MNE, 2006, p. 11) may imply that the curriculum did not only take this approach as its basis, but also objective, deterministic, linear and behavioristic instructional approaches which are synonymous with positivism(Under, 2010). On the other hand, there was a statement in the objectives section of the curriculum that "owing to the nature of science and scientific knowledge, time consuming instructional strategies and rediscovering everything were avoided at times" (MNE, 2006, p. 17). The phrase 'time consuming' is noteworthy as it may mean that some methods required by constructivism are not necessary for science. The view that rediscovering everything is unnecessary is also a serious contradiction.

\subsection{Objectivity and Subjectivity of Knowledge}

The approach of the national curriculum is not in line with radical constructivist philosophy and does not really consider subjective perceptions. It also diverges from radical constructivism in the objectives section by stating that the aim of science is to define and explain the physical and biological world (MNE, 2006). The presupposition of a physical and biological world and the statement that "this world exists independently from people's experiences" (MNE, 2006, p. 121) reveals a completely objectivist and positivist approach. The statement "science is not only a sum of worldly facts, but also a way of research and thinking that bases itself on experimental criteria and includes scientific methods" (MNE, 2006, p. 121) runs contrary to the view that the epistemological tradition and physical theories which aim to obtain a picture of the real world cannot take humans to an ultimate holistic truth (Glasersfeld, 2005a). Further, the phrase 'sum of worldly facts' is against the constructivist view that our beliefs about how the world runs are shaped by the meanings we derive from our experiences (Julyan \& Duckworth, 2005).

Some learning outcomes that reflect an objective and universal understanding of knowledge can be seen in the following examples (MNE, 2005) :

"Realizes there are ... real molecules" (p. 121),

"Says that the atom is actually three-dimensional" (p. 235),

"Realizes that the electron cloud model would be the most realistic perception" (p. 236),

"Realizes that the formulas represent a real molecule" (p. 315)

These outcomes are not aligned with the view of the constructivist approach that it is impossible to say that two people produce the same construct (Glasersfeld, 2005a). The word 'real' used in the outcomes shows that objects are independent from the mind and theories. This understanding and the similar understanding of objectivist and realistic 'knowing' generally constitute the learning outcomes aimed by teachers.

The understanding of scientific method

Ünder (2010) contends that some of the objectives mentioned in the curriculum such as "giving students the ability of scientific thinking ..., enabling students to use proper scientific processes and principles as they make personal decisions" (MNE, 2006, p. 8) show the privileged position given to the modernist enlightened and objectivist understanding of science. In addition, owing to Atatürk's treatment of science and rationality as superior to other intellectual traditions (MNE, 2005), the scientific understanding of the curriculum is closer to the positivist enlightened understanding than constructivism. On the other hand, the curriculum also states that methods are the dimension of science that experience less change. The aim is to have settled scientific methods thus emphasizing the prominent role given to the method of modernist enlightened knowledge production (MNE, 2006).

\subsection{Understanding the Nature of Scientific Knowledge}

The features of the curriculum that "individuals learn how to reach correct information by direct discovery, and they revise and reconstruct their world view as they learn" (MNE, 2005, p. 7) and students previous personal knowledge, views, beliefs, attitudes and goals affect learning (MNE, 2005) are in line with the view that the learning process is 
influenced by a set of conceptions or preconceptions that individuals have (Phillips, 1995). In contrast to this opinion, though, the curriculum largely includes common and universal learning outcomes for all students, such as students use the nature of science and scientific knowledge, scientific process skills in proper ways by understanding the principles, laws and theories of science (MNE, 2005).

While these outcomes are achieved, mislearning and misconceptions must be avoided. Of course, every learner has a standard set of correct concepts; however, a teacher with a constructivist point of view cannot assume that all students have reached an understanding through the same way of learning (Phillips, 1995). Besides, there is no explanation as to how teachers can overcome this sensitive issue. In addition, the statement that "owing to language and social interactions, there are similarities in the meaning patterns that individuals construct, and these meaning patterns may be converged as much as possible" (MNE, 2006, p. 13) also runs counter to the radical constructivist approach because it promotes an attitude that is contradictory to the main philosophy which asserts that the conceptual structures forming meaning or knowledge are individual constructs that cannot be used by different users, and that it is impossible and unnecessary for everyone to reach the same meaning (Glasersfeld, 2005a). Overall, positivist and postmodernist/constructivist values are intertwined in the 2004 curriculum, and a balance seems to have been sought. It may be said that the constructivist approach was the basis of learning strategies. However, the positivist perspective is inevitably dominant in the objectivity of knowledge. Even the clear writing of outcomes on the information level is a revelation of the positivist approach.

\section{Conclusion}

As shown in the first section, classical positivism was prominent both in the last century of Ottomans and during the Republican era. Although it was followed by the intellectuals of both eras, positivism was not a practice born out of profound Turkish scientific and philosophical debates. It was taken from the West as the basis of modernity, without first having experienced the period of Enlightenment that Westerners did. Due to this, positivist thinking was adopted but it was not clearly understood by the intellectuals as to what it entails. Particularly as a political discourse, there was a partially superficial positivist perspective. It therefore remained an imported thought used for ideological and political aims. However, it presented itself more clearly as both a method and a way of knowledge production in the objectives of the science course in the elementary curriculum of the Republican era. This was the case until the year 2004. The effects of the postmodern epistemological attitude started to partially be seen with the adoption of the "constructivist learning approach' by the new elementary curriculum initiated in 2004. However, this approach may also be said to work superficially and with an ideological orientation, similar to positivism which was copied from the West. Indeed, the constructivist approach was used mostly by the instructional practices and strategies of the Science and Technology Curriculum, and did not go beyond pedagogy.

At the heart of the 2004 curriculum lies pedagogical constructivism or, as claimed in the curriculum, the theoretical basis of the constructivist learning approach is psychological constructivism, and it has no problems with the knowledge production and legitimization methods of the classical understanding of positivist science. Active learning and individual discovery and meaning-making are strongly emphasized in the teaching of knowledge. The combination of classical epistemological hypotheses with pedagogical and psychological constructivism results in constructivism, which is said to be ordinary/trivial by Glasersfeld (2005b), and does not lead to a paradigm shift at all (Ünder, 2010). Constructivism as such has long been known by educators. Thus, the idea that learning should be actively constructed by the learner instead of being imposed by someone else is no news (Julyan \& Duckworth, 2005). The propositions of pedagogical constructivism can actually be dated back to Rousseau's progressive or new education approach. Thus, progressive approaches geared towards modern science and the scientific method are not new to Turkey. The same themes were evident even in the objectives of the science course included in the Elementary Curricula dated 1924 and 1926. Therefore, it would not be a speculative approach to refer to the 2004 curriculum as a political rather than an epistemological paradigm shift.

According to Lyotard, a proponent of Postmodernism, scientific knowledge has always been in conflict and competition with other ways of knowing (Lyotard, 1999). This viewpoint treats the self-legitimization process and function of scientific knowledge as another aspect of cultural imperialism. This stance is a critical attitude towards the legitimization project of modern science, legitimization methods based on scientific authority such as rationalization and secularization, and the resulting strength of modernity (Ginev, 2005). The main arguments of postmodernism are fed by epistemological relativism, scientific doubt, anti realism and overly social constructivism (Loving, 1997). Thus, a new dimension emerges in curriculum evaluation. Perhaps the problem is not the approach used by curriculum designers, but the fact that the epistemological issues belonging to postmodernist constructivism have particularly remained unresolved in the field of science.

On the other hand, the approach of radical relativism towards science education and the reductionist comment that 
"scientific knowledge is a type of discourse and both scientific and non-scientific knowledge is a proposal" (Lyotard, 1995, p. 10) mostly lead to a deadlock by treating science and its teaching (and the contents of the science curriculum) as a narrative, a discourse (Schulz, 2007). Established educational institutions and particularly the field of science are far from ensuring this approach. At the very least, the structure of scientific knowledge within history and institutions that have taught this have never organized themselves in line with this approach. The important point for the shift from a reality completely independent of culture, linguistic structure and the cognitive structure of the subject' to a probable, holistic, subjective/cognitivist understanding of reality by constructivist thinkers has been the questioning of the link between the knower and the known. This approach places the subject who knows at the center in the formation of mental representations. These claims go beyond those of Piaget, who stressed the formation of mental structures in learners, and other progressivist theories of learning. As is the case in radical constructivism, the link between the belief or concepts that the subject reaches while actively constructing knowledge and the objective reality is vanishing. This reduces radical constructivism and the learning approaches inspired by it to the same position as all anti-realist, anti-science, idealist and subjectivist philosophies. This subjectivist approach may be extended partially to subjective idealism and partially to radical relativism. In certain discourses, this approach is even sometimes in agreement, with Kant's view that individuals shape their experiences with a cognitive apparatus. Owing to his complicated epistemology, even Kant is claimed to be quintessentially constructivist (Phillips, 1995). However, the mentality problem that Kant treated as having a universal character shows that the constructivist approach cannot be reduced to individual experience and subjective way of perception.

The science debates that emerged in the postmodern era when the dominant viewpoint of modernity was challenged mostly by political motives. In Turkey and other similar countries with traditional and religious themes, the postmodern view is combined with a Kuhnian-type interpretation of science. Thus, thoughts such as legitimacy of scientific knowledge, the end of modernity and the demise of Western Enlightenment project are part flexible and part attractive. Starting from the belief that the scientific and the non-scientific can under no circumstances test each other (Lyotard, 1999), the proposal of a process based on the other narratives and text readings is more suitable for political aims (Aydın, 2007). In Phillips' (1995) words, the "quasireligious and ideological functions of these political aims constitute the ugly face of constructivism" (p. 11).

There still are debates on the possible outcomes of a science education whose epistemological bases are not understood and in which knowledge is reduced to beliefs and personal/subjective perception. In addition, the hypothesis that advancement and modernization can more easily be achieved by subjectifying the objective reality in the field of science education can result in a misleading process at least for societies that have not experienced the Enlightenment process.

In summary, in this study, the comparison of the phases dominant to the elementary science education programs in Turkey and postpozitivist / constructivist thesis of the constructivist approach dominant in 2004 program were questioned. While doing so, Turkey, the process of introduction of positivism, and it is reflected in the pedagogical relationship with the field of science has been defined. In addition, the effect of constructivist approach that is the educational application of post-modernist and postpositivist approaches in 2004 program with the effects of recent socio-cultural and political changes, contrary to positivist approach reinforcing its hegemony in the teaching of science with the Republican period and methods producing knowledge of science field is discussed. As with all the history of science, the relation of scientific thought with positivism in Turkey is quite old. But the effect of this relation through the formal school education programs took place in the last quarter-century of the Ottoman Empire. The effect of positivist approach, the dominant form of knowledge, especially to science is a natural development. There is parallelism between positivist approach and scientific knowledge understanding all over the world as well as in Turkey. The aims and applications of science education program particularly at primary level reflect this paradigm dominant to 2004 programs in the context of this realist and positivist idea. But the change in 2004 program seems to trying to locate the alternative and anti-positivist constructivist approach to the basis of aims. This is a fundamental change in perspective in such an area as science field. This change couldn't be reflected in real terms to the dimensions of aims in the program. Its reflection, as a matter of the field, is a difficult case as it requires a fundemental mental transformation in terms of social structure and philosophy of science. As can be seen in the study, the approaches of learning achievements and aims of science field of constructivist approach do not show anything different from positivist and objectivist conception of science. This only reinforces the idea that the trend has been used for the motivation of ideological and cultural resistance. However, while the matter should be discussed completely with epistemological and pedagocigal purposes, these approaches take place for political purposes in traditional countries such as Turkey. 


\section{References}

Adıvar, A. (1982). Osmanlı Türklerinde ilim [Science in Ottoman Turks]. Ankara: Remzi Kitabevi.

Ataünal, A., \& Özalp, R. (1977). Türk milli eğitiminde düzenleme teşkilatı [Organization in Turkish national education]. İstanbul: MEB Yayınları.

Aydın, H. (2007). Felsefi temeller ışı̆̆ında yapılandırmaclı [Constructivism in light of philosophical bases]. Ankara: Nobel.

Bahadır, O. (2001). Cumhuriyetin ilk bilim dergileri ve modernleşme [Early science journals in the republic and modernization]. İstanbul: İzdüşüm Yayınları.

Başgöz, İ. (1995). Türkiye’nin eğitim çıkmazı ve Atatürk. Ankara: Kültür Bakanlığı Yayınları.

Berkes, N. (1978). Türkiye'de çağdaşlaşma [Modernization in Turkey]. Istanbul: Doğu-Batı Yayınları.

Binbaşığlu, C. (1999). Cumhuriyet döneminde ilkokul programları [Elementary curricula in the republican period], In F. Gök (Ed.). 75 Yılda eğitim [Education in 75 years]. İstanbul: İş Bank-Tarih Vakfi Yayınları.

Birinci, N. (2006). Türk eğitim sisteminde yeni paradigma arayışları. Protokol konuşmaları [Protocol talks]. Retrieved February 03, 2010, from http://www.egitimbirsen.org.tr/dokuman/sempozyum_kitabi.pdf

Cromer, A. (1997). Connected knowledge: science, philosophy, and education. New York: Oxford University Press.

Fleury, S. C. (1998). Social studies, trivial constructivism and the politics of social knowledge. In M. Larochelle, N. Bednarz, \& J. Garrison (Eds.). Construnctivism and education, Cambridge: Cambridge University Press. http://dx.doi.org/10.1017/CBO9780511752865.011

Fosnot, C. T. (2005). Preface. In: C. T. Fosnot (Ed.). Constructivism: Theory, perspectives and practice. New York: Teachers College Press.

Ginev, D. (2005). Against the politics of postmodern philosophy of science. International Studies in the Philosophy of Science, 19(2), 191-208. http://dx.doi.org/10.1080/02698590500249522

Gök, F. (1999). 75 yılda insan yetiştirme eğitim ve devlet. In F.Gök (Ed.). 75 Yllda eğitim [Education in 75 years]. İstanbul: İş Bankası-Tarih Vakfı Yayınları.

Hanioğlu, Ş. (2008). Osmanlı popüler materyalizmi [Ottoman popular materialism]. Osmanlı Araştırmalart. http://www.osar.com/modules.php?name=News\&file=article\&sid=11530

Julyan, C., \& Duckworth, E. (2005). A Conctructivist perspective on teaching and learning science. In C. T. Fosnot (Ed.). Constructivism: Theory, perspectives and practice. New York: Teachers College Press.

Kafadar, O. (2000). Türkiye'de kültürel dönüşümler ve felsefe eğitimi [Cultural transformation in Turkey and education of phylosophy]. İstanbul: İz yayınc1lik

Koçer, H. A. (1987). Türkiye'de modern eğitimin doğuşu [The birth of modern education in Turkey]. Ankara: Uzman Yayınları.

Loving, C. C. (1997). From the summit of truth to its slippery slopes: Sciences education's journey through positivist-postmodern territory. American Educational Research Journal, 34(3), 421-452. http://dx.doi.org/10.3102/00028312034003421

Lyotard, J. F. (1999). The Postmodern condition -A report on knowledge-. Minnesota: The University of Minnesota Press.

Mardin, Ş. (1992). İdeoloji [Ideology]. İstanbul: İletişim.

Mardin, Ş. (1993). Jön türklerin siyasi fikirleri [Political ideas of young Turks]. İstanbul: İletişim.

MGE (1329/1913). Mekatib-i iptidaiye ve taliye ders programı [Elementary school curriculum]. İstanbul: Matbaa-i Amire.

MNE (2005). Fen ve teknoloji dersi (4 ve 5. sinıflar) ögretim programı [Science and technology course curriculum Grades 4 and 5]. http://ttkb.M.E.B..gov.tr/program.aspx?islem=1\&kno=24

MNE (2006). Fen ve teknoloji dersi (6, 7 ve 8. sinıflar) ögretim programı [Science and technology course curriculum Grades 6, 7 and 8]. http://ttkb.M.E.B..gov.tr/program.aspx?islem=1\&kno=25

MV (1341/1925). Illk mekteplerin müfredat programı [Elementary school curriculum]. İstanbul: Milli Matbaa.

MV (1926). İlk mekteplerin müfredat programı [Elementary school curriculum]. İstanbul: Devlet Matbas1. 
MV (1930). İlk mekteplerin müfredat programı [Elementary school curriculum]. İstanbul: Milli Matbaa.

MV [Maarif Vekâleti] (1340/1924). Illk mekteplerin müfredat programı [Elementary school curriculum]. İstanbul: Milli Matbaa.

Özlem, D. (2002). Türkiye'de pozitivizm ve siyaset [Positivism and politics in Turkey]. In T. Bora (Ed.). Modern Türkiye'de siyasi düşünce: Modernleşme ve batıcllk [Political thought in modern Turkey: Modernization and westernism]. İstanbul: İletişim.

Phillips, D. C. (1995). The good, the bad, and the ugly: The many faces of constructivism. Educational Researcher, 24(7), 5-12. http://dx.doi.org/10.3102/0013189X024007005

Schulz, R. M. (2007). Lyotard, postmodernism and science education: A rejoinder to Zembylas. Educational Philosophy and Theory, 39(6), 633-656. http://dx.doi.org/10.1111/j.1469-5812.2007.00301.x

Ülken, H. Z. (1992). Türkiye'de çağdaş düşünce tarihi [History of modern thought in Turkey]. İstanbul: Ülken Yayınları.

Unat, F. R. (1964). Türk eğitim sisteminin gelişmesine tarihi bir bakış [Development of Turkish education system: A historical point of view]. Ankara.

Ünder, H. (2010). Manifestations of epistemological theses of constructivism in the science and technology programs of Turkish elementary education. Education and Science, 35(158), 199-214.

von Glasersfeld, E. (2004). Constructivism. In W. E. Craighead \& C. B. Nemeroff (Eds.). Concise corsini encyclopedia of psychology and behavioral science (3. press) (pp. 219-220). New Jersey: John Wiley \& Sons. Inc.

von Glasersfeld, E. (2005a). Introduction: Aspects of constructivism. In C. T. Fosnot (Ed.). Constructivism: Theory, perspectives and practice. New York: Teachers College Press.

von Glasersfeld, E. (2005b). Thirty years radical constructivism. Constructivist Foundation, 1(1), 9-12.

Yavuz, H. (2009). Türkiye'nin zihin tarihi [Thought history of Turkey]. İstanbul: Timaş Yayınları.

\section{$(\mathrm{cc}) \mathrm{BY}$}

This work is licensed under a Creative Commons Attribution 3.0 License. 